\title{
Photovoltaic MPPT Research Based on Fuzzy-PID Dual-mode Control
}

\author{
Fei Wang ${ }^{1, a^{*}}$, Xianxiang $\mathrm{Li}^{2, \mathrm{~b}}$ \\ ${ }^{1}$ Foshan University, Foshan 528000, China \\ ${ }^{2}$ Foshan University, Foshan 528000, China \\ aemail : qdwf111@163.com
}

Keywords: PID; MPPT; Boost circuit; fuzzy control.

Abstract. This paper introduces the basic principle of Boost circuit topology and photovoltaic maximum power point tracking technology.According to the characteristics of photovoltaic cells output nonlinearity, this paper designs a fuzzy-PID controller to track the maximum power point of PV cell. The controller can control the voltage of photovoltaic cells.By changing the duty ratio of the switch tube and then control the output power of photovoltaic cells. The simulation model is established in Simulink. The simulation results show that the controller can track maximum power point of photovoltaic cell rapidly and stably.

\section{Introduction}

The world's energy shortage and pollution problems have become more and more serious. Development and utilization of clean, renewable energy has attracted much attention. Human beings must as soon as possible to seek a new alternative energy or renewable energy generation of natural energy. Research and practice show that energy of the direct solar radiation to the earth is rich and and does not pollute the environment. It is internationally recognized as the ideal alternative energy. Whether from the economic and social sustainable development, or from the earth ecological environment for human survival level to look at, the development and utilization of solar energy is of great strategic significance. The solar photovoltaic power generation is an important part of solar energy utilization. Photovoltaic cells affected by sunlight intensity and environmental temperature, the voltage will change and the output power will also change. The photovoltaic cell is a kind of unstable energy. Under different illumination and temperature conditions as far as possible electrical energy output, It has important significance to improve the power efficiency of solar cell. This paper presents a BOOST based circuit, It adopts fuzzy-PID double model control method to realize the solar maximum power point tracking.

\section{System model}

\section{The mathematical model of photovoltaic cells}

At present, the use of solar battery in photovoltaic system is mostly silicon solar cell. Figure 1 is the equivalent circuit of photovoltaic cells. The equivalent series resistance Rs of the ideal photovoltaic battery is small, and the equivalent parallel resistance $\mathrm{R}_{\mathrm{sh}}$ is very big. Usually for monocrystal line silicon or polycrystalline silicon photovoltaic cell, they can be ignored.

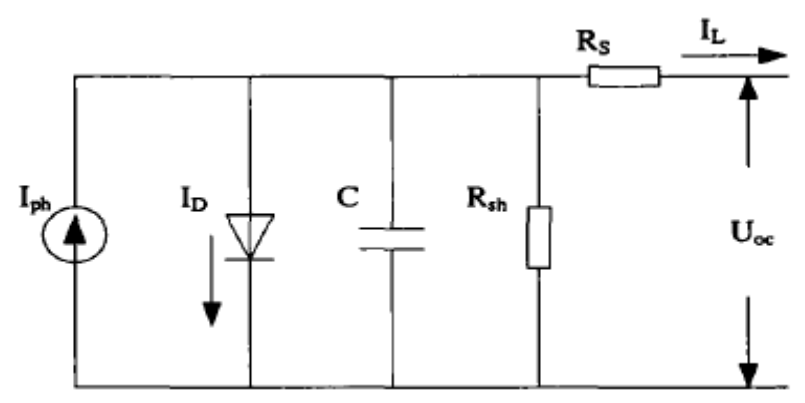

Fig. 1 Equivalent circuit of the photovoltaic battery 
Output characteristic equation of photovoltaic cells:

$I=I_{L}-I_{0}\left\{\exp \left[\frac{q\left(V+I R_{S}\right)}{A K T}\right]-1\right\}-\frac{V+I R_{S}}{R_{s h}}$

Formula 1 is the most basic analytical expressions based on physical principles, It has been widely applied in solar cell theory analysis, It is difficult to identify the parameters in the expression. solar cell model for Engineering usually requires several important technical parameters by suppliers, such as $\mathrm{I}_{\mathrm{sc}}, \mathrm{V}_{\mathrm{oc}}, \mathrm{I}_{\mathrm{o}}, \mathrm{V}_{\mathrm{o}}, \mathrm{P}$. The characteristics of reproduction can be in a certain precision array, and can facilitate the computer analysis. Output characteristic equation of photovoltaic cells:

$I_{p v}=I_{s c}\left(1-c_{1}\left(e^{\frac{V_{R}}{C_{2} V_{o c}}}-1\right)\right)+D I$

In the formula, $R_{S}$ is the series resistance of photovoltaic cells, $\mathrm{V}_{\mathrm{oc}}$ is an open circuit voltage, $\mathrm{V}_{\mathrm{mp}}$ 、 $\mathrm{I}_{\mathrm{mp}}$ are voltage and current corresponding to the maximum power point, $\alpha$ is temperature coefficient current changes $\left(\mathrm{Amps} /{ }^{\mathrm{O}} \mathrm{C}\right.$ ) In reference to sunlight condition, $\beta$ is the temperature coefficient of the voltage change $\left(\mathrm{V} /{ }^{\mathrm{O}} \mathrm{C}\right)$ In the reference temperature.

\section{PV cell characteristic}

I-V characteristic curve of solar cell is the most important aspect to photovoltaic system analysis. The I-V characteristics of photovoltaic cell is the relationship between the output voltage and output current of photovoltaic cell in a certain intensity of sunlight and temperature. shown in Figure 2. I-V curves indicated that the photovoltaic cell is not a constant voltage source and it is not a constant current source, It is a nonlinear DC power supply. Each point on the curve only corresponds with the output power of the photovoltaic cell on the operating voltage. $\mathrm{P}_{\mathrm{m}}$ is the maximum power output of the photovoltaic cell. $\mathrm{U}_{\mathrm{m}}$ and $\mathrm{I}_{\mathrm{m}}$ are voltage and current of solar cell at the maximum power point. At a certain temperature and sunlight intensity, the maximum power point of photovoltaic cell is the only one. photovoltaic cell characteristics is shown in Figure 2.

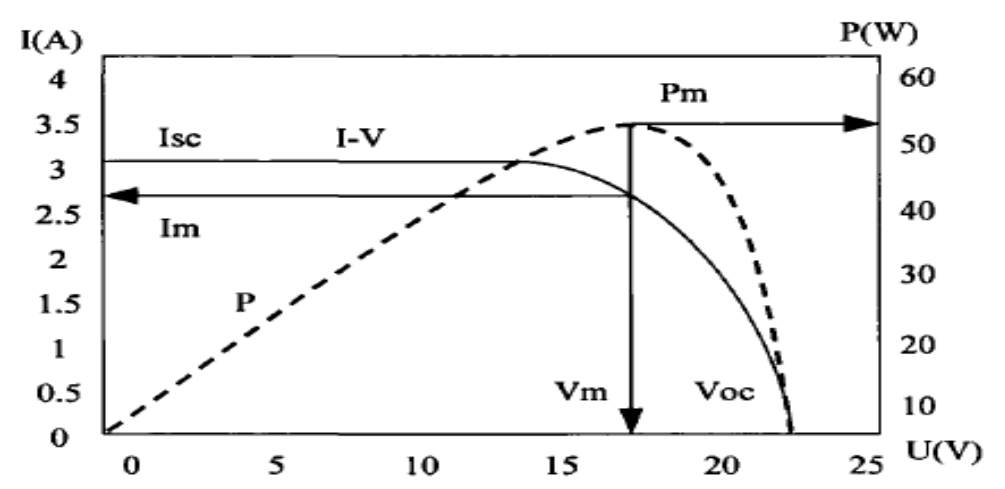

Fig. 2 The volt ampere characteristic curve of PV cells

\section{The main circuit of Boost}

The system uses Boost converter, It is a kind of switching DC voltage boost circuit and can make the output voltage higher than the input voltage. It has the advantages of simple structure, high efficiency, small size advantages. As shown in Figure 3.

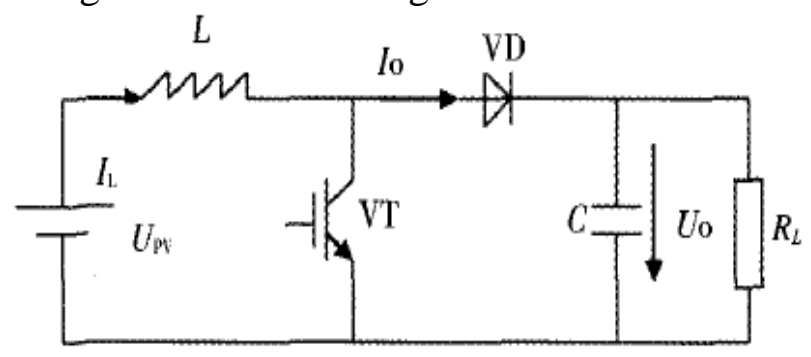

Fig.3 Topology of Boost circuit

A large value of assuming inductance $\mathrm{L}$, Boost circuits work in continuous current mode (CCM), The current is substantially constant. The capacitor value $\mathrm{C}$ is great. VT conduction time is Ton, 
Inductance L stored energy is $U_{P V} I_{l} T_{o n}$. When the VT is in off state, $U_{P V}$ and L together charge to capacitor C, and provide energy to the load RL, VT off time is Toff, During this period, the inductance energy released is $\left(U_{o}-U_{p v}\right) I_{l} T_{o f f}$. When the circuit is in a steady job, a period T inductance energy absorption and release of energy are equal.

$U_{P V} I_{l} T_{o n}=\left(U_{o}-U_{p v}\right) I_{l} T_{o f f}$

The duty ratio: $D=\frac{T_{o n}}{T}=\frac{T_{o n}}{T_{\text {on }}+T_{\text {off }}}$

So The relationship of output voltage and the duty cycle:

$U_{o}=\frac{T_{o n}+T_{o f f}}{T_{o f f}} U_{p v}=\frac{1}{1-D} U_{p v}$

Based on the formula 4, the output voltage of the photovoltaic cell is proportional to the duty cycle.

\section{Design of the controller}

\section{Design of PID controller}

The control algorithms of digital PID controller :

$u(k)=K_{p}\left\{e(k)+\frac{T}{T i} \sum_{j=0}^{k} e(j)+\frac{T d}{T}(e(k)-e(k-1))\right\}$

In order to facilitate the computer program, the above formula becomes Formula 6:

$u(k)=K_{p} e(k)+K_{i} \sum_{j=0}^{k} e(j)+K_{d}[e(k)-e(k-1)]$

$e(k)$ In the formula is input of the digital PID controller; $e(j)$ is the deviation of $\mathrm{k}$ sampling time; $u(k)$ is the $\mathrm{K}$ point sampling output of digital PID controller; $\mathrm{T}$ is the sampling period, $K_{i}$ is the integral coefficient, $K_{i}=K_{p} \frac{T}{T_{i}} ; K_{d}$ is the differential coefficient, $K_{d}=K_{p} \frac{T_{d}}{T}$;

Incremental digital PID control algorithm:

$\Delta u(k)=u(k)-u(k-1)=K_{p}[e(k)-e(k-1)]+K_{i} e(k)+K_{d}[e(k)-2 e(k-1)+e(k-2)]$

The control variable of digital PID controller is the duty ratio of $\mathrm{D}$ and the deviation signal is $\Delta P$, it can find the maximum power point according to figure 2 and figure 3 , The relationship between $\Delta D$ and $\Delta P$ :

(1)If $\Delta U(k)>0$ and $\Delta P>0$, At this point in the left side of the maximum power point, the duty ratio should continue to increase, That is $\Delta D>0$; If $\Delta U(k)>0$ and $\Delta P<0$, At this point in the right side of the maximum power point, the duty ratio should be reduced, That is $\Delta<0$;

(2)If $\Delta U(k)<0$ and $\Delta P>0$, At this point in the right side of the maximum power point, the duty ratio should continue to reduce, That is $\Delta<0$; If $\Delta U(k)<0$ and $\Delta P<0$, At this point in the left side of the maximum power point, the duty ratio should be increased, That is $\Delta D>0$;

According to the above analysis, When $\Delta U(k)>0$ the output power and duty cycle the same direction change, When $\Delta U(k)<0$ The output power and duty cycle reverse direction change, incremental digital PID controller can be designed According to the $\Delta U(k)$ situation:

If $\Delta U(k)>0$, then

$\Delta D(k)=D(k)-D(k-1)=K_{p}[\Delta P(k)-\Delta P(k-1)]+K_{i} \Delta P(k)+K_{d}[\Delta P(k)-2 \Delta P(k-1)+\Delta P(k-2)]$

if $\Delta U(k)<0$, then

$\Delta D(k)=D(k)-D(k-1)=-\left\{K_{p}[\Delta P(k)-\Delta P(k-1)]+K_{i} \Delta P(k)+K_{d}[\Delta P(k)-2 \Delta P(k-1)+\Delta P(k-2)]\right\}$ 
PID Matlab simulation model was set up as shown in figure 4. The two unit delay module are respectively output power $\mathrm{P}$ and output voltage $\mathrm{V}$ of a sampling period of delay.

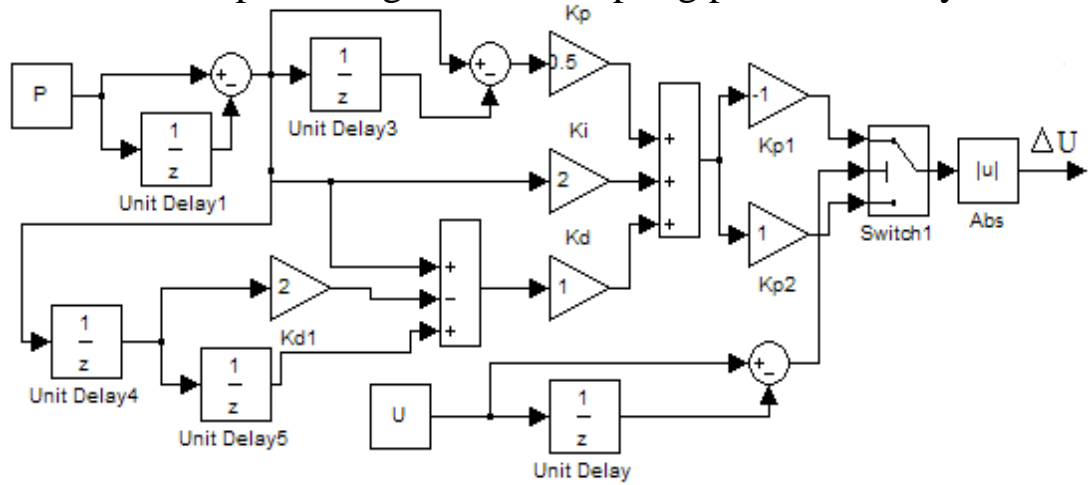

Fig.4 PID controller simulation model

\section{Design of MPPT fuzzy controller}

\section{Input and output of fuzzy controller}

We can see from Figure 2, the output voltage changes of photovoltaic cells, can make the maximum output power of photovoltaic cells 。 formula (3) shows that the Boost circuit in continuous current mode $(\mathrm{CCM})$ work, the output voltage is proportional to the duty cycle. The input variables of fuzzy controller can chose power variable $\Delta \mathrm{P}$ and voltage variable $\Delta \mathrm{U}$. Output duty is ratio $\mathrm{D}$. The output voltage of photovoltaic cell change by controlling the duty ratio, The maximum output power points of photovoltaic cells can be found.

\section{Fuzzy subset and domain of input and output variables}

The actual value of voltage variation Eu (n) and the power variation Ep (n) and the duty ratio of step size $\mathrm{Ed}(\mathrm{n})$ Respectively using the quantization factor are mapped to fuzzy set theory domain $\mathrm{Eu} 、 \mathrm{Ep}$ and Ed.Eu, Ep and Ed are defined as 5 fuzzy subsets Negative big (NB), negative small (NS), zero (Z), Positive small (PS ),Positive big (PB) Were used to express. That is:

$\mathrm{Eu}=\{\mathrm{NB}, \mathrm{NS}, \mathrm{Z}, \mathrm{PS}, \mathrm{PB}\}$

$\mathrm{Ep}=\{\mathrm{NB}, \mathrm{NS}, \mathrm{Z}, \mathrm{PS}, \mathrm{PB}\}$

$\mathrm{Ed}=\{\mathrm{NB}, \mathrm{NS}, \mathrm{Z}, \mathrm{PS}, \mathrm{PB}\}$

Fuzzy set theory domain Eu、Ep and Ed use the discrete digital collection, hat is:

$\mathrm{Eu}=\{-6,-5,-4,-3,-2,-1,0,+1,+2,+3,+4,+5,+6\}$

$\mathrm{Ep}=\{-6,-5,-4,-3,-2,-1,0,+1,+2,+3,+4,+5,+6\}$

$\mathrm{Ed}=\{-6,-5,-4,-3,-2,-1,0,+1,+2,+3,+4,+5,+6\}$

\section{Membership function}

In the fuzzy control rules, language variable value of Ev, Ep and Ed are NB, NM, NS, Z, PS, PM and $\mathrm{PB}$, Their membership functions are triangular wave, and each variable width range is equal。 Their membership function as shown in Figure 5

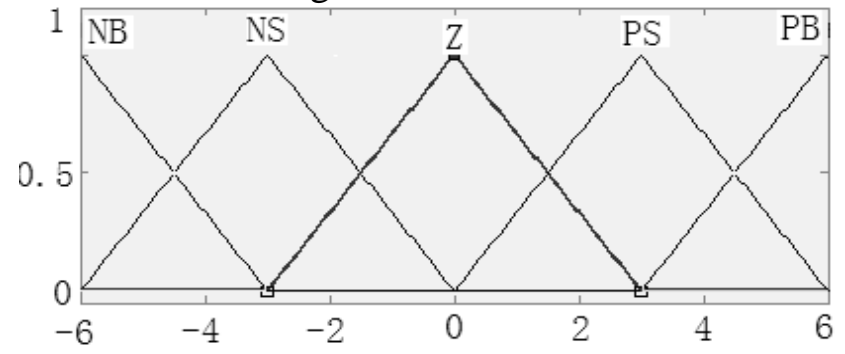

Fig.5 Membership function

\section{Fuzzy decision table}

According to the relationship between output power $\mathrm{P}$ of photovoltaic cells and output voltage $\mathrm{U}$ and and the relationship between output power $\mathrm{P}$ of photovoltaic cells and duty ratio $\mathrm{D}$, we can get the following principles:

If $\mathrm{U}$ increases and $\mathrm{P}$ increases, Pmax is on the left of MPP, the duty is increased, If $U$ increases and $P$ reduces, Pmax is on the right of MPP, the duty is reduced, 
If $\mathrm{U}$ reduces and $\mathrm{P}$ increases, Pmax is on the right of MPP, the duty is reduced, If $\mathrm{U}$ reduces and P reduces, Pmax is on the left of MPP, the duty is increased, The obtained fuzzy control rule table as shown in Table 1

Tab.1 Fuzzy control rule table

\begin{tabular}{cccccc}
${\Delta_{V}}_{\Delta_{P}}$ & NB & NS & Z & PS & PB \\
\hline NB & PB & PM & PS & NM & NB \\
NS & PM & PS & PS & NS & NM \\
Z & PS & PS & Z & NS & NS \\
PS & NM & NS & NS & PS & PM \\
PB & NB & NM & NS & PM & PB \\
\hline
\end{tabular}

Matlab simulation model is established According to the mathematical model of PV array and fuzzy control rule table, shown in Figure 6. The two unit delay module are respectively output power $\mathrm{P}$ and output voltage $\mathrm{V}$ of a sampling period of delay

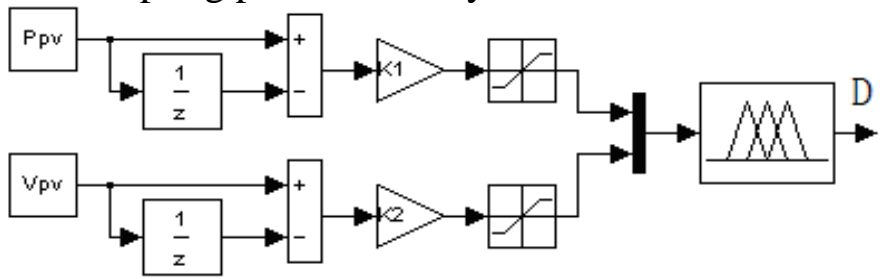

Fig.6 Model of simulation control

\section{results of simulation analysis}

System uses simulink module in matlab to establish the model of PV array and uses the Fuzzy Logic module to establish the fuzzy inferential control system. Photovoltaic cell parameter setting: The short-circuit current $I_{s c}=4.5 \mathrm{~A}$, open circuit voltage $V_{o c}=42 \mathrm{~V}$, photovoltaic cell series resistance $R_{s}=0.1 \Omega$, In a photovoltaic cell reference temperature, taking the temperature coefficient of current change $\left(\mathrm{Amps} /{ }^{\circ} \mathrm{c}\right) \alpha=0.0012 I_{s c}$, voltage variation coefficient $\left(\mathrm{V} /{ }^{\circ} \mathrm{c}\right) \beta=0.005 \mathrm{~V}_{o c}$, The output voltage corresponding to the maximum power point is $V_{m p}=34 \mathrm{~V}$ and the output current is $I_{m p}=3.5 \mathrm{~A}$. The graph 7 9 are simulation results of the voltage output of photovoltaic cells, the current and power output of photovoltaic cells in the standard conditions of temperature, sunshine intensity in the second seconds from the $600 \mathrm{~W} / \mathrm{m}^{2}$ suddenly increased to $1000 \mathrm{~W} / \mathrm{m} 2$, the fourth seconds from the $1000 \mathrm{~W} / \mathrm{m}^{2}$ suddenly reduced to $800 \mathrm{~W} / \mathrm{m}^{2}$. The figure 7 is the output voltage curve of PV cell, figure 8 is the current output curves of photovoltaic cells, figure 9 is the output power curve.

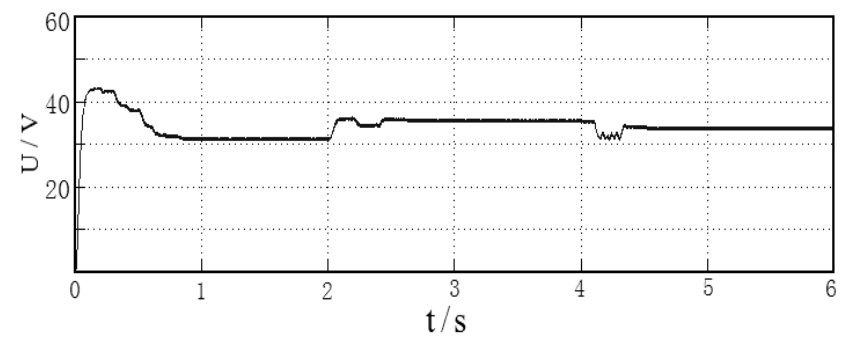

Fig.7 voltage output curve 


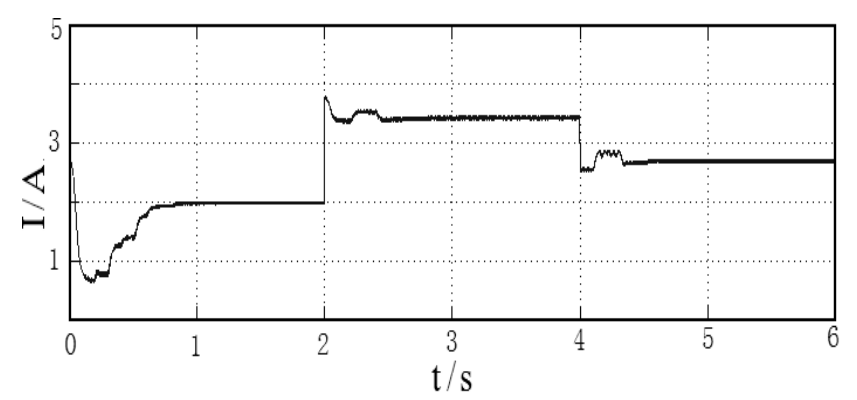

Fig.8 output current curve

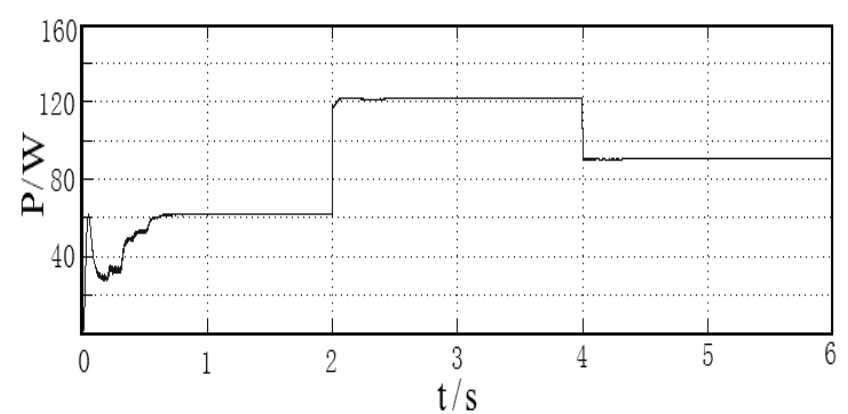

Fig. 9 power output curve

The initial conditions are zero, appearance of the $600 \mathrm{~W} / \mathrm{m}^{2}$ light suddenly, the controller can track maximum power point rapidly and no shocks near the maximum power point. Then the maximum power output of photovoltaic cells is about $61.8 \mathrm{~W}$, the output voltage is about $30.6 \mathrm{~V}$, the output current is about 2.0A. By the time of the second seconds, the light intensity suddenly increased from $600 \mathrm{~W} / \mathrm{m}^{2}$ to $1000 \mathrm{~W} / \mathrm{m}^{2}$, after about $100 \mathrm{~ms}$ or so, the fuzzy controller with a fast response to quickly find the maximum power point. Then the maximum power output of photovoltaic cells is about $121.6 \mathrm{~W}$, the output voltage is about $35.8 \mathrm{~V}$, the output current is about $3.4 \mathrm{~A}$. When the time of the fourth seconds, the light intensity from the $1000 \mathrm{~W} / \mathrm{m}^{2}$ suddenly dropped to $800 \mathrm{~W} / \mathrm{m}^{2}$, the fuzzy controller find the maximum power point quickly. Then the maximum power output of photovoltaic cells is about $90.7 \mathrm{~W}$, the output voltage is about $34.9 \mathrm{~V}$, the output current is about $2.6 \mathrm{~A}$. From the simulation results, the fuzzy controller of sudden changes in the environment can quickly find the maximum power output point. After the fuzzy controller find the maximum power point, the PID controller can make the PV cells at maximum power point.

\section{Conclusion}

As photovoltaic cells are more sensitive to sunlight intensity, using the fuzzy -PID double mode controller to control the boost circuit, realize the PV maximum power point tracking. The simulation results show that fuzzy controllers can find the maximum power point rapidly when the change of light intensity, PID controller can achieve high precision control after the fuzzy controller to find the maximum power point.

\section{References}

[1] S. Yuvarajan, Dachuan Yu, Shanguang Xu, A novel power converter for photovoltaic applications, J. Power Sources135 (1-2) (2004) 327-331.

[2] Z.d. Zhong, H.b Huo,. X.j Zhu,. G.y. Cao, Y Ren, Adaptive maximum power point tracking -control of fuel cell power plants, J. Power Sources, 176 (1) (2008) 259-269.

[3] Ibrahim, H.E.-S.A. Houssiny, F.F. El-Din, H.M.Z. El-Shibini, M.A, Microcomputer controlled buck regulator for maximum power pointtracker for DC pumping system operates from photovoltaic system, Proceedings of the IEEE

International Conference on Fuzzy Systems FUZZ IEEE'99, 1 (1999) 406-411. 
[4] Lopes Luiz A.C., Lienhardt Anne-Marie, A simplified nonlinear power sourcefor simulating PV panels. In: Proc. IEEE power electronics specialist conf; 2003.p. 1729-34.

[5] Enslin Johan HR, Wolf Mario S, Snyman Dani“el B, Swiegers Wernher. Integrated photovoltaic maximum power point tracking converter. IEEE Trans Industrial Electronics December 1997;44:769-73.

[6] Radziemska E, Klugmann E. Photovoltaic maximum power point varying with illumination and temperature. J. Solar Energy Eng. February 2006;128(1):34-9. 